\title{
東南アジア関係文献目録 （2003年11月～2004年10月）
}

この文献目録は，2003年11月から2004年10月までの期間に日本国内で刊行された， 東南アジアの歴史と文化に関わる文献を採録したものである（前号の調査に漏れた文 献についてはこれ以外のものも採録した)。現在のインドネシア, カンボジア, シンガ ポール, タイ, 東ティモール, ビルマ, フィリピン, ブルネイ, ベトナム, マレーシ ア, ラオスに相当する地域に関する文献のほか, 雲南・広西地方に関わる文献を含ん でいる。

全体を「書籍の部」と「論文の部」に分け，上記の国別に分類できるものは国別に 分類し, それ以外は〈一般〉に分類した。外国語文献, 邦語文献の順に配列し, 外国 語文献は著者・編者のアルファベット順, 邦語文献は五十音順に配列した。

各項目の内容は以下の通りである。

書籍の部：(1)著者名(2)書名(3)出版社名(4)総頁数(5)刊行年月(6)税別価格

論文の部：(1)著者名(2)論文名(3)掲載誌・書名(4)頁数(5)刊行年月 *論文を収録して いる書籍が「書籍の部」に採録されている場合は，(3)掲載雑誌・書籍名の項は「国別 分類：編者名」の形式でその書籍を指示している。

紙幅の関係上，以下の採録基準で文献を取捨選択した（学会ウェブページからダウ ンロードできる電子版文献目録にはここに採録しなかった文献も含まれている)。

i . 戦記類, ガイドブック類, ビジネス関連書, 語学テキスト, 滞在記・旅行記・エ ッセイ類, 新装版・復刻版は採録しない。

ii 。書籍（論文集や報告書など）の全体構成において主題的統一性が高い場合，個々 の論文は採録せず，単行本として「書籍の部」に採録する。また，一部雑誌の特集 号も，同様に「書籍の部」に採録する。

iii．東南アジア関係の論文を 1 本しか載せない書籍は,「書籍の部」に採録しない（た だし, ii を優先する)。

iv。「論文の部」には，注を備えたものを採録する（講座物などはこの限りでない）。

論文については, 会員からの自己申告分のほか, 国立情報学研究所の学術コンテン ツ・ポータルから該当書誌を加え, 内容の判然としないものは立教大学, 早稲田大学, 東京大学の各附属図書館などにおいて現物を確認した。単行本については, 会員から の自己申告分を基に, 学術コンテンツ・ポータル, 日本出版販売株式会社の「本や夕 ウン」などのウェブページや OPACで確認し得た該当書誌を採録し，内容の判然とし ないものは現物を確認した。 


\section{$\langle$ 一 般〉}

(1) Furukawa Hisao, Nishibuchi Mitsuaki, Kono Yasuyuki, Kaida Yoshihiro (2) Ecological Destruction, Health, and Development: Advancing Asian Paradigms (Kyoto Area Studies on Asia 8) (3)京都大学学術出版会(4) 638 (5) 04/02 (6) 9765 (1)(2)アジア動向年報 2004 (3)アジア経済研究所(4) 646 (5) 04/05 (6) 6615

(1)青柳＼cjkstart健二(2)アジアの棚田日本の棚田：オリザを旅する(3)平凡社(4) 112 (5) 04/07 (6) 3360

(1)ヴィニョー・K・アガワル，浦田 秀次郎（編）(2アジアにおける日本企業の成功 物語：市場戦略と非市場戦略の分析(3)早稲田大学出版部(4) 327 (5) 04/05 (6) 4500

(1)秋道 智彌(2)コモンズの人類学：文化・歷史・生態(3)人文書院(4)245(5)04/09 (6) 2730

(1)浅野 豊美，松田 利彦（編）(2)植民地帝国日本の法的構造(3)信山社出版(4) 477 (5) 04/03 (6) 4935

(1)浅野 豊美，松田 利彦（編）(2)植民地帝国日本の法的展開(3)信山社出版(4) 415 (5) 04/06 (6) 4410

(1)アジア・太平洋人権情報センター（編）(2)企業の社会的責任と人権（アジア太平洋 人権レビュー 2004) (3)現代人文社(4) 260 (5) 04/06 (6) 2940

(1)フィリップ・G・アルトバック (編), 森 利枝 (訳) (2)私学高等教育の潮流（高等 教育シリーズ 128）(3)玉川大学出版部(4) 253 (5) 04/10 (6) 4725

(1)飯田 和美(2)クメールの遺跡に魅せられて(3)文芸社(4) 222 (5) 04/09 (6) 1470

(1)池上 良正（他編）(2)絆：共同性を問い直す（岩波講座 宗教 6) (3)岩波書店(4) 295 (5) $04 / 06$ (6) 3570

(1)池上 良正（他編）(2)宗教の挑戦（岩波講座 宗教 9） (3)岩波書店(4)293(5)04/07 (6) 3570

(1)石 南国，早瀬 保子 (編) (2)アジアの人口問題：21 世紀への展望と戦略（シリー ズ人口学研究 10) (3)原書房(4) 234 (5) 04/01 (6) 3360

(1)泉田 洋一(2)農村開発金融論：アジアの経験と経済発展(3)東京大学出版会(4) 221 (5) $03 / 12$ (6) 6510

(1)板垣 明美(2)癒しと呪いの人類学(3)春風社(4) 349 (5) $03 / 11$ (6) 2940

(1)岩㴊 功一（編）(2)越える文化，交錯する境界：トランス・アジアを翔るメディア 文化（アジア理解講座 3） (3)山川出版社(4) 213 (5) 04/03 (6) 1890

(1)薄木 秀夫(2)メコン発アジアの新時代：現代世界読本(3)凱風社(4) 269 (5) 04/05 (6) 1890

(1)馬越 徹(2)アジア・オセアニアの高等教育（高等教育シリーズ 129）(3)玉川大学出 版部(4) 258 (5) 04/09 (6) 4725

(1)浦野 起央（編著）(2)資料体系アジア・アフリカ国際関係政治社会史 第 2 巻 [第 3 
分冊 q ] (3)パピルス出版(4) 6/557/1 (5) 03/12 (6) 50400

(1)浦野 起央 (編著) (2)資料体系アジア・アフリカ国際関係政治社会史 第 2 巻 [第 3 分冊 r ] (3)パピルス出版(4) 6/435/1 (5) 04/06 (6) 44100

(1)浦野 起央 (編著) (2)資料体系アジア・アフリカ国際関係政治社会史 第 2 巻 [第 4 分冊 d] (3)パピルス出版(4) 3/526/23 (5) 04/05 (6) 50400

(1)浦野 起央 (編著) (2)資料体系アジア・アフリカ国際関係政治社会史 第 2 巻 [第 4 分冊 e] (3)パピルス出版(4) 3/514/1 (5) 04/07 (6) 48300

(1)浦野 起央 (編著) (2)資料体系アジア・アフリカ国際関係政治社会史 第 2 巻 [第 4 分冊 f ] (3)パピルス出版(4) 3/561/23 (5) 04/09 (6) 50400

(1)大泉 光一（編著）(2)次の標的は日本：アジア系イスラム過激派組織とテロ対策(3) ジャパンインターナショナル総合研究所(4) 242 (5) 04/06 (6) 1575

(1)大沢 真理 (編著) (2)アジア諸国の福祉戦略（講座 福祉国家のゆくえ4）(3)ミネ ルヴァ書房(4) 346/3 (5) 04/06 (6) 3675

(1)大谷 信介（編著）(2)問題意識と社会学研究(3)ミネルヴァ書房(4) 288 (5) 04/03 (6) 2940

(1)大庭 三枝(2)アジア太平洋地域形成への道程：境界国家日豪のアイデンティティ模 索と地域主義 (Minerva 人文・社会科学叢書 95) (3)ミネルヴァ書房(4) 431/13 (5) 04/ 08 (6) 6300

(1)大橋 康二(2)海を渡った陶磁器（歴史文化ライブラリー 177）(3)吉川弘文館(4) 231 (5) $04 / 06$ (6) 1785

(1)大村 次郷(2)遺跡が語るアジア：カラー版(3)中央公論新社(4) 219 (5) 04/04 (6) 1029

(1)加藤 剛 (編著) (2)変容する東南アジア社会 : 民族・社会・文化の動態(3)めこん(4) 479 (5) 04/10 (6) 3990

(1)鎌沢 久也(2)メコン街道：母なる大河 4200 キロを往く(3)水曜社(4) 159 (5) 04/07 (6) 1890

(1)私市 正利, 栗田 禎子（編）(2)イスラーム地域の民衆運動と民主化（イスラーム 地域研究叢書 3) (3)東京大学出版会(4) 310 (5) 04/01 (6) 5040

(1)岸川 毅, 岩崎 正洋 (編) (2)アクセス地域研究 1：民主化の多様な姿(3)日本経 済評論社(4) 227 (5) $04 / 06$ (6) 2940

(1)北原 淳, 西沢 信善 (編著) (2)アジア経済論(3)ミネルヴァ書房(4) 322 (5) 04/11 (6) 3360

(1)北村 一郎(2)アクセスガイド外国法(3)東京大学出版会(4) 540 (5) 04/06 (6) 5250

(1)木畑 洋一（編著）(2) 20 世紀の戦争とは何であったか（講座 戦争と現代 2) 大月書店(4) 304 (5) 04/03 (6) 2800

(1)木村 一信(2)昭和作家の〈南洋行〉 (3)世界思想社(4) 394 (5) 04/04 (6) 7140

(1)国宗 浩三，久保 公二（編）(2)金融グローバル化と途上国（研究双書 536）(3) ジア経済研究所(4) 370 (5) 04/01 (6) 4305

(1)久保 英之(2)アジアの森と村人の権利：ネパール・タイ・フィリピンの森を守る活 
動(3)現代書館(4) 222 (5) 03/11 (6) 2100

(1)久保 文明，赤木 完爾（編）(2)メリカと東アジア（現代東アジアと日本 6) (3) 慶応義塾大学出版会(4) 289 (5) 04/08 (6) 3570

(1)K・クラム, H・カラス (編), 田村 勝省（訳) (2)東アジアの統合：成長を共有す るための貿易政策課題(3)シュプリンガーフェアクラーク東京(4) 188 (5) 04/07 (6) 3360

(1)黒羽 清隆(2)太平洋戦争の歴史（講談社学術文庫) (3)講談社(4) 413 (5) 04/08 (6) 1260

(1)小出 武夫（編）(2)在南洋邦人団体便覧（アジア学叢書 108) (3)大空社(4) 119/14 (5) 04/02 66 5250

(1)小松 久男, 小杉 泰（編）(2)現代イスラーム思想と政治運動（イスラーム地域研 究叢書 2) (3)東京大学出版会(4) 354 (5) 03/12 (6) 5040

(1)佐藤 考一(2)獅子の町・海峡の風：マラッカ 3 国の社会・文化・自然(3)めこん(4) 165 (5) $04 / 06$ (6) 1995

(1)澤田 貴之(2)アジア経済論：移民・経済発展・政治経済像(3)創成社(4) 205/7 (5) 04/ 04 (6) 2415

(1)関根 政美，山本 信人（編）(2)海域アジア（現代東アジアと日本 4) (3)慶応義塾 大学出版会(4) 341 (5) 04/06 (6) 3570

(1)拓殖大学国際開発研究所 (編) (2)国際開発学研究 3 (3)勁草書房(4) 123 (5) 04/07 (6) 1500

(1)武内 進一 (編著) (2)国家・暴力・政治：アジア・アフリカの紛争をめぐって（研 究双書 534) (3)アジア経済研究所(4) 510 (5) 03/12 (6) 5460

(1)田村 慶子, 織田 由紀子 (編著) (2)東南アジアの NGO とジェンダー(3)明石書店 (4) 271 (5) $04 / 02$ (6) 3150

(1)多屋 勝雄（編著) (2)アジアのエビ養殖と貿易(3)成山堂書店(4) 188 (5) 03/12 (6) 2730

(1)筑波大学文化批評研究会（編）(2)〈翻訳〉の圈域：文化・植民地・アイデンティテ 1(3)イセブ(4) 590 (5) 04/02 (6) 2500

(1)辻＼cjkstart雅男(2)アジアの農業近代化を考える：東南アジアと南アジアの事例から（KUA RO 叢書 3) (3)九州大学出版会(4) 126 (5) 04/05 (6) 1050

(1)道明 三保子 (監修) (2)国別すぐわかる世界の染め・織りの見かた(3)東京美術(4) 135 (5) $04 / 08$ (6) 1995

(1)トーマツ (編) (2)アジア諸国の税法＼cjkstart第 4 版：主要 10 カ国・地域の税制のすべて(3) 中央経済社(4) 662 (5) 03/12 (6) 9975

(1)21世紀 COE プログラム「史資料ハブ地域文化研究拠点」総括班 (編) (2)史資料ハブ : 地域文化研究 No.3 (3)東京外国語大学大学院地域文化研究科 COE拠点(4)255 (5) $04 / 03$ (6)非売品

(1)日外アソシエーツ (編) (2)アジア・アフリカ関係図書目録 1999-2003 (3)日外アソシ エーツ(4) 768 (5) 04/09 (6) 29820

(1)日本中小企業学会 (編) (2)アジア新時代の中小企業（日本中小企業学会論集 23）(3) 
同友館(4) 198 (5) 04/06 (6) 2940

(1)日本比較教育学会紀要編集委員会（編）(2)特集・高等教育改革の比較研究：法人 化・民営化を中心として（比較教育学研究 30）(3)東信堂(4) 239 (5) 04/07 (6) 2625

(1)日本比較政治学会（編）(2)比較のなかの中国政治（日本比較政治学会年報 6) (3)早 稲田大学出版部(4) 221 (5) 04/06 (6) 3360

(1)根本 敬 (編) (2)東南アジアにとって 20 世紀とは何か：ナショナリズムをめぐる思 想状況 (AA 研東南アジア研究 第 6 巻) (3)東京外国語大学アジア・アフリカ言語文 化研究所(4) 254 (5) 04/03 6)非売品

(1)ピーター・ハークレロード (著), 熊谷 千寿（訳）(2)謀略と紛争の世紀：特殊部 隊・特務機関の全活動(3)原書房(4) 669/16 (5) 04/04 (6) 3990

(1)長谷川 啓之（編著）(2)グローバル化時代のアジア経済：持続的成長の可能性(3)創 土社(4) 350 (5) 04/06 (6) 3150

(1)一橋大学経済研究所経済制度研究センター-(編), 寺西 重郎 (責任編集) (2)アジア のソーシャル・セーフティネット(3)勁草書房(4) 298 (5) 03/12 (6) 4200

(1)弘末 雅士(2)東南アジアの港市世界：地域社会の形成と世界秩序（世界歴史選書） (3)岩波書店(4) $214 / 22$ (5) 04/05 (6) 2730

(1)深田 祐介(2)大東亜会議の真実：アジアの解放と独立を目指して（PHP 新書）(3) PHP 研究所(4) 329 (5) 04/03 (6) 840

(1)ヨハン・ポチエ (著), 山内 彰, 西川 隆（訳）(2)食糧確保の人類学：フード・セ キュリティー（りぶらりあ選書）(3法政大学出版局(4) 356/29 (5) 03/12 6) 4200

(1)前田 富稘，野村 雅昭 (編) (2)漢字の未来 (朝倉漢字講座 5) (3)朝倉書店(4) 255 (5) $04 / 04$ (6) 5040

(1)松本 逸也(2)「脱垔」の群像：大日本帝国漂流(3)人間と歴史社(4) 267 (5) 04/06 (6) 2100

(1)三浦 徹, 岸本 美緒, 関本 照夫（編）(2)比較史のアジア：所有・契約・市場・ 公正（イスラーム地域研究叢書 4) (3)東京大学出版会(4) 310 (5) 04/02 (6) 5040

(1)宮武 正道(2)南洋の言語と文学 (アジア学叢書 103) (3)大空社(4) 298/25 (5) 04/02 (6) 10185

(1)矢作 敏行（編）(2)中国・アジアの小売業革新：全球（グローバル）化のインパク 卜(3)日本経済新聞社(4) 304 (5) 03/11 (6) 3990

(1)山中 美由紀（編）(2)変貌するアジアの家族：比較・文化・ジェンダー（龍谷大学 国際社会文化研究所叢書 2) (3)昭和堂(4) 277/5 (5) 04/03 (6) 3150

(1)やまもと くみこ(2)中国人ムスリムの末裔たち：雲南からミャンマーへ (Sapio 選 書) (3)小学館(4) 318 (5) 04/06 (6) 1470

(1)山脇 直司，丸山 真人，柴田 寿子（編）(2)グローバル化の行方（ライブラリ相 関社会科学 10) (3)新世社(4) 349 (5) 04/07 (6) 2520

(1)吉田 康彦(2)現代アジア最新事情 3 版：21 世紀アジア・太平洋諸国と日本(3)大阪 経済法科大学(4) 390 (5) 04/10 (6) 2730 
(1)吉野 直行(2)アジア金融危機とマクロ経済政策(3)慶応義塾大学出版会(4) 276 (5) 04/ 06 (6) 3990

(1)米村 明夫（編著）(2)世界の教育開発：教育発展の社会科学的研究(3)明石書店(4) 276 (5) $03 / 12$ (6) 4200

(1)四方田 犬彦(2)アジア映画の大衆的想像力(3)青土社(4) 383 (5) 03/11 (6) 2940

(1)依光 良三 (編著) (2)破壊から再生へ：アジアの森から(3)日本経済評論社(4) 287 (5) $03 / 12$ (6) 2520

(1)フィリップ・ローソン (著), レヌカー・M, 永井 文, 白川 厚子 (訳) (2)東南ア ジアの美術(3)めこん(4) 421/16 (5) 04/03 (6) 1890

(1)渡辺 利夫 (編), 日本総合研究所調査部環太平洋研究センター(著) (2)東アジア経 済連携の時代(3)東洋経済新報社(4) 243 (5) 04/08 (6) 2730

\section{〈インドネシア〉}

(1)石田 正美 (編) (2)対インドネシア開発援助の現状と課題：日系企業のニーズの反 映と累積債務問題への対応(3)アジア経済研究所(4) 421 (5) 04/03 (6)非売品

(1)板垣 與一 (著), 板垣 哲史（編) (2)自己の中に永遠を(3)文芸社(4) 338 (5) 04/04 (6) 1890

(1)井上 真(2)コモンズの思想を求めて：カリマンタンの森で考える（新世界事情）(3) 岩波書店(4) 162 (5) 04/01 (6) 1785

(1)奥野 克巳(2)「精霊の仕業」と「人の仕業」：ボルネオ島カリス社会における災い解 釈と対処法(3)春風社(4) 313 (5) 04/02 (6) 6800

(1)加納 啓良(2)現代インドネシア経済史論：輸出経済と農業問題（東京大学東洋文化 研究所報告 東洋文化研究所紀要 別冊) (3)東京大学出版会(4) 376 (5) 04/02 (6) 8190

(1)木村 公一(2)インドネシア教会の宣教と神学：開発と対話と解放の神学の間で(3)新 教出版社(4) 387 (5) 04/04 (6) 3150

(1)黒岩 郁雄（編）(2)開発途上国におけるガバナンスの諸課題：理論と実際（経済協 カシリーズ 第 203 号) (3)アジア経済研究所(4) 322 (5) 04/02 (6) 3885

(1)小牧 利寿(2)ゴム時間共和国インドネシア：楽天大国の素顔(3)日本経済新聞社(4) 263 (5) $04 / 05$ (6) 1890

(1)世界経済情報サービス(2)インドネシア 2003（ARCレポート）(3)世界経済情報サー ビス(4) 139 (5) 03/12 (6) 16800

(1)高橋 澄子（他著）(2)アジアの伝統医学（伝統医学シリーズ） (3)出帆新社(4) 207 (5) 04/06 (6) 2835

(1)冨尾 武弘(2)インドネシア古代史の謎：幻のガルー王国(3)インドネシア文化観光セ ンター(4) 255 (5) 04/09 (6) 1000

(1)ミルダ・ドリューケ (著), 畔上 司 (訳) (2)海の漂泊民族バジャウ(3)草思社(4) 390/ 12 (5) $03 / 11$ (6) 3045

(1)永井 重信(2)激動のインドネシア 1996-2003 (3)アイダム樹と匠社(4) 286 (5) 04/05 
東南アジア 一 歴史と文化 - No.34,2005

(6) 2100

(1)西木 正明(2)わが心，南溟に消ゆ（集英社文庫）(3)集英社(4) 490 (5) 04/02 (6) 1000

(1)福岡 良男(2)軍医のみた大東覀戦争：インドネシアとの邂逅(3)暁印書館(4) 205 (5) $04 / 05$ (6) 2800

(1)プラムディア・アナンタ・トゥール (著), 山田 道隆 (訳) (2)日本軍に棄てられた 少女たち：インドネシアの慰安婦悲話(3)コモンズ(4) 278 (5) 04/08 (6) 2940

(1)本台 進 (編著) (2)通貨危機後のインドネシア農村経済(3)日本評論社(4) 224 (5) 04/08 (6) 6090

(1)松井 和久 (編) (2)インドネシアの地方分権化：分権化をめぐる中央・地方のダイ ナミクスとリアリティー（研究双書 533）(3アアジ経済研究所(4) 284 (5) 03/12 6) 3360

(1)見市 建(2)インドネシア：イスラーム主義のゆくえ（平凡社選書 222）(3)平凡社(4) 203 (5) 04/08 (6) 2310

(1)宮城 大蔵(2)戦後アジア秩序の模索と日本：「海のアジア」の戦後史 1957-66 (3)創 文社(4) 294 (5) $04 / 10$ (6) 4410

(1)村井 吉敬，佐伯 奈津子（編著）(2)インドネシアを知るための 50 章（エリア・ス タディーズ) (3)明石書店(4) 273 (5) 04/07 (6) 2100

(1)頼富＼cjkstart本宏(2)聖なるものの形と場(3)法蔵館(4) 578/86 (5) 04/03 6) 9975

(1)鷿見 一夫(2)住民泣かせの『援助』：コトパンジャン・ダムにおける人権侵害と環 境破壊(3)明空出版(4) 595 (5) 04/01 (6) 2520

\section{〈カンボジア〉}

(1)今関 信子(2)地雷の村で「寺子屋」づくり：カンボジアひとり NGO 栗本英世の挑戦 (愛と希望のノンフィクション) (3) PHP 研究所(4) 186 (5) 03/11 (6) 1365

(1)上杉 勇司(2)変わりゆく国連 $\mathrm{PKO}$ と紛争解決：平和創造と平和構築をつなぐ(3)明 石書店(4) 326 (5) $04 / 06$ (6) 3990

(1)高橋 宏明（編訳）(2)ンボジアの民話世界(3)めこん(4) 141 (5) 03/12 (6) 1575

(1)パル・ヴァンナリーレアク（著）, 岡田知子（訳）(2)カンボジア花のゆくえ（現代 アジアの女性作家秀作シリーズ) (3)段々社(4) 211 (5) 03/10 (6) 1995

(1)廣畑 伸雄(2)カンボジア経済入門：市場経済化と貧困削減(3)日本評論社(4) 184 (5) 04/01 (6) 2625

(1)藤井 秀樹(2)カンボジアと子どもたちの戦後：地雷・貧困・エイズ・人身売買(3) 精社(4) 222 (5) 04/04 (6) 1680

(1)ペン・セタリン(2)クメール語入門：カンボジア語(3)連合出版(4) 335 (5) 04/05 (6) 2625

(1)三留 理男(2)悲しきアンコール・ワット（集英社新書）(3)集英社(4) 221 (5) 04/08 6) 735

(1)山田 寛(2)ポル・ポト〈革命〉史：虐殺と破壊の四年間（講談社選書メチエ）(3)講 
談社(4) 232 (5) 04/07 (6) 1680

\section{〈シンガポール〉}

(1)岡田＼cjkstart桂典(2)六つの国歌を歌った人の住む国(3)東京図書出版会(4) 165 (5) 04/03 (6) 1365

(1)川村 湊(2)海を渡った日本語：植民地の「国語」の時間＼cjkstart新装版(3)青土社(4) 303 (5) $04 / 04$ (6) 2520

(1)胡 暁子(2)日本人が知らない「日本の姿」：シンガポール財閥総裁夫人からの警告(3) 小学館(4) 239 (5) 04/02 (6) 1575

(1)小竹 裕一(2)シンガポールから学んだこと：南洋に 20 年生きて(3)明石書店(4) 292 (5) $04 / 04$ (6) 2625

(1)酒井 亨(2)哈日族 (ハーリーズー)：なぜ日本が好きなのか（光文社新書）(3)光文社 (4) 228 (5) $04 / 05$ (6) 735

(1)清水 洋(2)シンガポールの経済発展と日本(3)コモンズ(4) 242 (5) 04/05 (6) 2940

(1)日本植民地教育史研究会運営委員会（編）(2)植民地教育の残痕（植民地教育史研究 年報 6) (3)晧星社(4) 177 (5) 04/04 (6) 2100

(1)原 清治, 山内 乾史, 杉本 均 (編) (2)教育の比較社会学(3)学文社(4) 236 (5) 04/01 (6) 1680

(1)丸山 真人, 内田 隆三 (編), 樺山 紘一 (他監修) (2)〈資本〉から人間の経済へ： 20 世紀を考える 3（ライブラリ相関社会科学 9）(3)新世社(4) 252 (5) 04/02 (6) 2100 (1)湯沢 雍彦 (編著) (2)里親制度の国際比較（ミネルヴァ社会福祉叢書 12）(3)ミネル ヴァ書房(4) 347 (5) 04/05 (6) 5250

(1)ウイリアム・S・W・リム(著), 宇高 雄志(訳)(2) 21 世紀アジア都市の未来像： シンガポール人建築家の挑戦（明石ライブラリー 65） (3)明石書店(4) 266 (5) 04/08 (6) 3150

\section{〈タ イ〉}

(1)(2)夕イ経済・産業データハンドブック 2003年版(3)アジア産業研究所(4)406(5)04/ 07 (6) 47250

(1)(2)バンコク：国際化の中の劇場都市（アジア遊学 57）(3)勉誠出版(4) 199 (5) 03/11 (6) 1890

(1)市野沢＼cjkstart潤平(2)ゴーゴーバーの経営人類学：バンコク中心部におけるセックスッー リズムに関する微視的研究(3)めこん(4) 301 (5) 04/01 (6) 2730

(1)末廣 昭(2)進化する多国籍企業：いま，アジアで何が起きているのか？（新世界事 情）(3)岩波書店(4) 158 (5) 03/11 (6) 1785

(1)世界経済情報サービス（2)夕イ 2004（ARCレポート）（3)世界経済情報サービス(4) 189 (5) $04 / 03$ (6) 16800

(1)谷口 巳三郎(2)熱帯に生きる：在タイ 20 年, 農村開発に命を捧ぐ（国際ボランティ 
ア活動記 2) (3)北部夕イ農村振興支援会(4) 277 (5) 04/08 6) 1300

(1)トンチャイ・ウィニッチャクン (著), 石井 米雄 (訳) (2)地図がつくったタイ：国 民国家誕生の歴史（明石ライブラリー 54）(3)明石書店(4) 414 (5) 03/11 6) 4179

(1)松尾＼cjkstart康範(2)イサーンの百姓たち：NGO 東北タイ活動記(3)めこん(4) 231 (5) 04/01 (6) 1680

(1)矢田部会（編著）(2)特命全権公使矢田部保吉(3)個人書店(4) 354 (5) 02/12 6)非売品

(1)谷津 弘(2)泰緬鉄道をゆく：戦場にかける橋 六十年ぶりの再訪の旅(3)朝文社(4) 123 (5) $03 / 11$ (6) 1890

(1)山本 博史(2) F T A とタイ農業・農村（筑波書房ブックレット 暮らしのなかの食 と農 18）(3)筑波書房(4) 63 (5) 04/01 (6) 788

\section{〈東ティモール〉}

(1)稲田 十一 (編) (2)紛争と復興支援：平和構築に向けた国際社会の対応(3)有斐閣(4) 303 (5) 04/05 (6) 2520

(1)亀崎 善江(2)神の慈しみの島東ティモール：草の根医療チームの記録(3)女子パウロ (4) 253 (5) $03 / 12$ (6) 1470

\section{〈ビル マ〉}

(1)アジア仏教徒協会 (編著) (2)赤と緑の大地で：ミャンマーをゆく 20 年(3)不知火書房 (4) 142 (5) $04 / 08$ (6) 2000

(1)伊東＼cjkstart照司(2)ビルマ仏教遺跡(3)柏書房(4) 422/31 (5) 03/11 (6) 29400

(1)大場 四千男(2)戦時期日本資本主義の戦略と組織(3)北樹出版(4) 202 (5) 03/11 (6) 2625

(1)世界経済情報サービス（編）（2)ミャンマー 2003（ARCレポート）（3)界経済情報 サービス(4) 136 (5) 04/01 (6) 16800

(1)武島 良成(2)日本占領とビルマの民族運動：タキン勢力の政治的上昇(3)竜渓書舎(4) 285 (5) $03 / 11$ (6) 8400

(1)西島 伊三雄 (著)，西島 雅幸（編）(2)画帖緬甸：西島伊三雄二等水兵スケッチ (3)海鳥社(4) 112 (5) $03 / 11$ (6) 3990

(1)フティン・アウン (著)，野口 栄一郎（訳）(2)ヤンゴン河の虹：ミャンマー民話集 (3)文芸社(4) 130 (5) $03 / 12$ (6) 1050

(1)マウン・ミンニョウ，重田 做弘(2)日本からみた祖国ビルマ（母と子でみる A 36） (3)草の根出版会(4) 143 (5) 04/03 (6) 2310

(1)ミンテインカ (著), 高橋 ゆり（訳）(2)マヌサーリー(3)てらいんく(4) 247 (5) 04/08 (6) 1800

(1)邸 景一，武田 和秀(2)ミャンマー：仏教遺跡の宝庫を歩く（旅名人ブックス 63） (3)日経 BP 社(4) 220 (5) $03 / 12$ (6) 1890 


\section{〈フィリピン〉}

(1)五十嵐 誠一(2)フィリピンの民主化と市民社会：移行・定着・発展の政治力学(3)成 文堂(4) 280 (5) 04/04 (6) 3675

(1)池端 雪浦, リディア・N・ユー・ホセ（編）(2)近現代日本・フィリピン関係史(3) 岩波書店(4) 659/18 (5) 04/02 (6) 6510

(1)レイナルド・C・イレート, ビンセンテ・L・ラファエル, フロロ・C・キブイェ ン (著), 永野善子 (編・監訳) (2)フィリピン歴史研究と植民地言説(3)めこん(4) 389 (5) $04 / 08$ (6) 2940

(1)駒井 洋 (編著) (2)多文化社会への道（講座 グローバル化する日本と移民問題 6) (3)明石書店(4) 382 (5) $03 / 12$ (6) 4830

(1)世界経済情報サービス (編) (2)フィリピン 2003（ARCレポート）(3)世界経済情報 サービス(4) 168 (5) $04 / 07$ (6) 16800

(1)関根 康正 (編) (2)〈都市的なるもの〉の現在：文化人類学的考察(3)東京大学出版 会(4) 529 (5) $04 / 02$ (6) 9240

(1)永野 善子(2)フィリピン銀行史研究：植民地体制と金融(3)御茶の水書房(4) $356 / 31$ (5) $03 / 12$ (6) 7140

(1)原 勝洋(2)真相・カミカゼ特攻：必死必中の 300 日(3)ベストセラーズ(4) 254 (5) 04/ 04 (6) 2625

(1)森谷 裕美子(2)ジェンダーの民族誌：フィリピン・ボントックにおける女性と社会 (3)九州大学出版会(4) 465 (5) 04/02 (6) 8610

(1)山本 宗補(2)フィリピン最底辺を生きる（岩波フォト・ドキュメンタリー世界の戦 場から) (3)岩波書店(4) 77 (5) 03/12 (6) 1890

(1)渡邊 薰(2)比律賓在留邦人商業発達史（アジア学叢書 105）(3)大空社(4) 360/39 (5) 04/02 (6) 12075

\section{〈べトナム〉}

(1)(2)アジアからのメッセージ：ベトナム映画の現在（アジアフォーカスブックレット 3）(3)アジアフォーカス・福岡映画祭実行委員会(4) 31 (5) 04/03 6) 210

(1)青柳 真智子（編）(2)老いの人類学（Sekaishiso Seminar）(3)世界思想社(4) 250 (5) 04/03 6) 1890

(1)安斎 育郎 (他著) (2)ホーチミン市の戦争証跡博物館ガイドブック(3)ウンかもが わ(4) 55 (5) $03 / 11$ (6) 1000

(1)今井 昭夫, 岩井 美佐紀（編著）(2)現代べトナムを知るための 60 章（エリアスタ ディーズ）(3明石書店(4) 383 (5) 04/06 (6) 2100

(1)片岡 利昭(2)ベトナム進出日系企業リスト：完全収録 2004 (3)ビスタピーエス(4) 314 (5) $04 / 07$ (6) 10500

(1)神田 嘉延, ファム・フー・ロイ, 関 隆通(2)ベトナムの自立発展と生涯学習（ア ジア・南太平洋の生涯学習シリーズ) (3)高文堂出版(4) 203 (5) 03/11 (6) 2300 
(1)菊池 誠一(2)ベトナム日本町の考古学(3)高志書院(4) 317 (5) 03/11 (6) 6930

(1)グエン・ニャット・アィン (著), 加藤＼cjkstart栄（訳) (2)つぶらな瞳(3)てらいんく(4) 295 (5) $04 / 08$ (6) 1800

(1)経営労働協会 (監修), 関 満博, 長崎 利光 (編) (2)ベトナム：市場経済化と日本 企業(3)新評論(4) 395 (5) $04 / 04$ (6) 4725

(1)白石 昌也 (編著) (2)ベトナムの対外関係 (21 世紀の挑戦) (3)暁印書館(4) 251 (5) 04/ 09 (6) 3990

（1)世界経済情報サービス（編）（2)ベトナム $2003 （$ ARC レポート）（3)世界経済情報サ ービス(4) 124 (5) 04/03 (6) 16800

(1)千葉 文人(2)リアル・ベトナム：改革・開放の新世紀(3)明石書店(4) 396 (5) 04/06 (6) 2415

(1)西村 昌也, 西野 範子 (著) (2)ヴェトナム紅河平原遺跡デー夕集 (文部科学省科学 研究費研究報告) (3)(4) 309 (5) 03/06 6)非売品

(1)日越貿易会(2)ベトナム統計年鑑 2002 年版 (3)ビスタピーエス (4) 496 (5) 04/02 (6) 36750

(1)春山 成子(2)べトナム北部の自然と農業：紅河デルタの自然災害とその対策(3)古今 書院(4) 131 (5) 04/05 (6) 3780

(1)レ・カオ・ダイ (著), 尾崎 望（監訳）(2)ベトナム戦争におけるエージェントオレ ンジ : 歴史と影響(3)文理閣(4) 145 (5) 04/04 (6) 1890

\section{〈マレーシア〉}

(1)石井 貫太郎(2)リーダーシップの政治学（現代臨床政治学シリーズ 1) (3)東信堂(4) 164 (5) 04/04 (6) 1680

(1)エヌ・エヌ・エー(2)マレーシア会社法(3)エヌ・エヌ・エー(4) 529 (5) 03/12 (6) 31500

(1)富沢 寿勇(2)王権儀礼と国家：現代マレー社会における政治文化の範型(3)東京大学 出版会(4) $322 / 20$ (5) $03 / 12$ (6) 8190

(1)マハティール・ビン・モハマド (著), 加藤 暁子（訳）(2)立ち上がれ日本人（新潮 新書) (3)新潮社(4) 187 (5) $03 / 12$ (6) 714

(1)マハティール・ビン・モハマド (著), 橋本 光平 (訳・構成) (2)日本人よ。成功の 原点に戻れ：真のグローバリゼーションを目指して(3) PHP 研究所(4) 213 (5) 04/02 (6) 1575

\section{〈ラオス〉}

(1)乾＼cjkstart美紀(2)ラオス少数民族の教育問題(3)明石書店(4) 223 (5) 04/02 (6) 4200

(1)中田 友子(2)南ラオス村落社会の民族誌：民族混住状況下の「連帯」と闘争(3)明石 書店(4) 329 (5) 04/02 (6) 6825 


\section{〈光 の 他〉}

(1)荒井 悦代 (編著) (2)東部南アジア地域の地域関係：研究会中間成果報告(3)アジア 経済研究所(4) 229 (5) 04/03 (6)非売品

(1)石島 紀之(2)雲南と近代中国：周辺の視点から（シリーズ中国にとっての 20 世紀) (3)青木書店(4) $10 / 317 / 8$ (5) $04 / 03$ (6) 3570

(1)波平 元辰 (編著) (2)雲南の「西部大開発」：日中共同研究の視点から（アジア太平 洋センター研究叢書 14) (3)九州大学出版会(4) 235 (5) 04/01 (6) 2940

(1)西野 留美子(2)戦場の「慰安婦」：拉孟全滅戦を生き延びた朴永心の軌跡(3)明石書店 (4) 230 (5) $03 / 12$ (6) 2310

\section{論文の部}

\section{$\langle$ 一 般〉}

(1) François Bourguignon, Chor-Ching Goh (2)インドネシア, 韓国, および夕イの貿 易と労働市場の脆弱性(3)一般：クラム，カラス (編) (4) 165-180 (5) 04/07

(1) Jehan Arulpragasam, Francesco Goletti, Tamar Manuelyan Atinc, Vera Songwe (2)負困層にとって重要な分野の貿易：カンボジアとベトナムのコメ，およびモ ンゴルのカシミア(3)一般：クラム，カラス (編) (4) 145-164 (5) 04/07

(1) Kono Yasuyuki, A.T. Rambo (2) Some Key Issues Relating to Sustainable Agro-resources Management in the Mountainous Region of Mainland Southeast Asia (3)東南アジア研究 41(4) (4) 550-565 (5) 04/03

(1) Mari Pangestu, Sudarshan Gooptu (2)新たなリージョナリズム：東アジアの選択 肢(3)一般：クラム，カラス (編) (4) 39-57 (5) 04/07

(1) Maung Maung Lwin, 作野 久美子(2)開発における社会的・文化的要因の概観：儒 教文化を中心に(3)海外事情研究 32(1)（熊本学園大学) (4) 75-105 (5) 04/09

(1) Takamura Kazue (2) Not "Divided Places”, But “A Living Space”: Chinese Women on the Thai-Malaysian Border (3)アジア・アフリカ言語文化研究 68（東 京外国語大学) (4) 173-191 (5) 04/09

(1)赤木 完爾(2)東アジアにおける安全保障秩序の展望：アメリカの視角(3)一般：久保, 赤木（編）(4) 109-130 (5) 04/08

(1)秋田 茂(2)グローバルヒストリーとアジア世界（特集 歴史としてのグローバリゼ ーション) (3) Ex Oriente 10 (大阪外国語大学) (4) 75-90 (5) 04/02

(1)芦澤 成光, 高千穂 安長, 所 伸之(2)夕イ・ベトナムにおける日系家電企業の経 営実態調査報告書：平成 14 年度経営学部共同研究報告書(3)論叢：玉川大学経営学 部紀要 3 (4) 77-95 (5) 03/12

(1)阿部 修人, 久保 克行(2)アジア通貨危機と雇用調整：企業パネルデータを用いた 分析(3)一般：一橋大学経済研究所経済制度研究センター(編) (4) 265-291 (5) 03/12 
東南アジア 一 歴史と文化 - No.34,2005

(1)荒井 幹夫(2)アセアン諸国でのマスコミ規制と報道の自由：東南アジア主要 5 カ国 での聞き取り調査から(3)東洋学園大学紀要 12 (4) 59-74 (5) 04/03

(1)メリ・アンソニー(2)A S E A N安保共同体に向けて(3)海外事情 52(3) (拓殖大学) (4) 34-45 (5) 04/03

(1)井口 泰(2)アジアの外国人労働者：地域統合と国際労働力移動(3)一般：大沢（編）

(4) 131-152 (5) 04/06

(1)井口 由布(2) B・アンダーソン「想像の共同体」再考：「文化」概念の脱構築(3)一 般：「史資料ハブ地域文化研究拠点」総括班（編）（東京外国語大学） (4) 51-66 (5) 04/ 03

(1)石戸 光(2)フィリピンとマレーシア：対外統合度を契機とした発展（特集 新経済 発展論：経済史比較から見えるもの) (3)アジ研ワールド・トレンド 109 (4)16-19(5) $04 / 10$

(1)井上 治(2)東南アジアのテロリスト群像(3)海外事情 52(4)（拓殖大学) (4) 43-57 (5) 04/04

(1)大沢＼cjkstart真理(2)東アジア諸国の福祉戦略と開発戦略(3)一般：大沢 (編) (4) 1-21 (5) 04/ 06

(1)太田 辰幸(2)アジアの海外直接投資と国際分業の新展開：電子産業の事例(3アジア 文化研究所研究年報 38 (東洋大学) (4) 23(144)-48(119) (5) 04/02

(1)大庭 三枝(2)アジアにおける地域主義の展開(3)一般：関根・山本 (編) (4) 11-39 (5) 04/06

(1)岡 伸一(2) ILO のアジア戦略：インフォーマルセクターへの社会保障の適用を目 指して(3)一般：大沢 (編) (4) 249-276 (5) 04/06

(1)小笠原 高雪(2)アメリカの東南アジア政策：米越関係の回顧と展望(3)一般：久保, 赤木 (編) (4) 91-108 (5) 04/08

(1)小柏＼cjkstart葉子(2)太平洋島嶼フォーラムと東アジア(3)一般：関根・山本 (編) (4) 261-280 (5) $04 / 06$

(1)奥島 美夏(2)北カリマンタン州分立運動の源流：現代国家成立期におけるインドネ シア・マレーシア国境地方の経験(3) JAMS News 29 (日本マレーシア研究会) (4) 13-25 (5) 04/06

(1)奥田 英信, 三重野 文晴(2)東南アジアの金融発展 : 開発金融パラダイムの変化と 多様性(3)国際協力論集 12(1)（神戸大学）(4) 57-84 (5) 04/08

(1)小野 耕二(2)比較政治学の新たな可能性：アジア諸国の政治をいかに比較するか(3) 一般：日本比較政治学会（編）(4) 1-24 (5) 04/06

(1)加藤 剛(2)民族・宗教・文化の動態的理解を目指して：東南アジアのフィールドか ら(3)一般：加藤 (編) (4) 7-21 (5) 04/10

(1)上村 泰裕(2)東アジアの福祉国家：その比較研究に向けて(3)一般：大沢 (編) (4) 23 -65 (5) $04 / 06$

(1)菊地 茂雄, 塚本 勝也(2)米軍の共同演習の傾向とアジア太平洋の安全保障(3)防衛 
研究所紀要 6(2) (4) 92-114 (5) 03/12

(1)菊池 陽子(2) 1940 年代初期のラオスに対する夕イの宣伝活動とフランスの対応(3) 一般：根本 (編) (4) 23-38 (5) 04/03

(1)北嶋 守(2)アジア規模のモノづくりの進展と国内産業集積の再構築：競合モデルと 協働モデルの視点から(3)一般：日本中小企業学会（編）(4) 47-60 (5) 04/06

(1)國谷 徹(2)東南アジア（2003年の歴史学界：回顧と展望）(3)史學雜誌 113(5) (4) 865-870 (5) 04/05

(1)栗原 浩英(2)コミンテルンの東南アジアへのアプローチ(3)一般：根本 (編) (4) 111130 (5) $04 / 03$

(1)栗原 充代, 山形 辰史(2)開発戦略としての Pro-Poor Growth：負困層への雇用創 出(3)国際開発研究 12(2) (4) 3-28 (5) 03/11

(1)後藤 康浩(2)アジアのエネルギー安全保障：日本に必要な「新思考」(3)国際問題 524 (4) $15-29$ (5) $03 / 11$

(1)菅谷 広宣(2)東南アジアの社会保障：戦略はあるのか? (3)一般：大沢（編）(4) 183220 (5) 04/06

(1)鈴木 陽一(2)冷戦のなかの東南アジア 1961-1968：インドネシア・マレーシアを 中心に(3)東南アジア：歴史と文化 33 (4) 119-136 (5) 04/05

(1)角野 猛(2)日本, 中国, 韓国及び東南アジアの伝統塩蔵発酵食品に関する総合的研 究（平成 15 年度日本調理科学会学会賞受賞記念論文）(3)日本調理科学会誌 37(2) (4) 124-134 (5) $04 / 05$

(1)高岡 正信，タウィーシン・スップワッタナー(2)近くて遠い隣人：タイ，ラオ民族 間関係の歴史的展開(3)一般：加藤 (編) (4) 93-143 (5) $04 / 10$

(1)高田 洋子(2)房総の歴史と下総台地の開拓：メコンデルタ開拓との比較から (3) (3) 環境情報研究 12 (敬愛大学) (4) 97-112 (5) 04/04

(1)高埜 健(2)海域アジアの安全保障：海賊問題をめぐる地域協力を中心に(3)一般：関 根・山本 (編) (4) 63-89 (5) 04/06

(1)武田 康裕(2)東南アジアと「民主化の波」(3)一般：関根・山本（編）(4) 131-156 (5) $04 / 06$

(1)土屋 忍(2)森三千代にみる戦時「南洋」文学の可能性：1940 年前後・翻案としての 安南伝説(3)一般：筑波大学文化批評研究会（編）(4) 101-122 (5) 04/02

(1)ロバート・ティアニー(2)南洋を「西洋眼鏡」で見る(3)一般：筑波大学文化批評研究 会 (編) (4) 39-57 (5) 04/02

(1)寺西 重郎(2)アジアのソーシャル・セーフティネット(3)一般：一橋大学経済研究所 経済制度研究センター (編) (4) 3-14 (5) 03/12

(1)冨尾 武弘(2)海のシルクロードのひとこま(3)東洋史苑 62（龍谷大学）(4) 20-37 (5) $04 / 01$

(1)永田 伸吾(2)ヴェトナム・カンボジア紛争と「人道的介入」：その評価と問題点(3)社 会環境研究 9 (金沢大学) (4) 43-53 (5) 04/03 
(1)長津 一史(2)越境移動の構図：西セレベス海におけるサマ人と国家(3)一般：関根・ 山本 (編) (4) 91-128 (5) 04/06

(1)長谷川 英夫(2)東南アジアにおける農業教育の役割と国際貢献の在り方：筑波アジ ア農業教育セミナー 25 年のあゆみ（課題 熱帯開発途上国における農業教育の役 割：社会開発の基盤活動）(3)熱帯農業 48 (EXTRA 1) (4) 137-141 (5) 04/03

(1)ハディ・スサストロ(2)A S E A N 経済共同体(3)海外事情 52(3)（拓殖大学）(4) 2-17 (5) $04 / 03$

(1)花見 槙子 (2)異文化理解の諸相：東南アジア社会におけるジェンダーの考察を通 して(3)三重大学留学生センター紀要 5 (4) 1-13 (5) 03/03

(1)林 行夫(2)活きる〈周縁〉，摇らぐ〈中心〉：移動する夕イ系民族の国境域での仏教 実践(3)一般：加藤（編） (4) 144-200 (5) 04/10

(1)速水 洋子(2)夕イ・ビルマ国境域の〈カレン〉から見る民族と宗教の動態(3)一般： 加藤（編）(4) 201-244 (5) 04/10

(1)ピッチ・ニツマー(2)A S E A Nの競争力：財政と金融(3)海外事情 52(3)（拓殖大学) (4) $18-33$ (5) $04 / 03$

(1)平山 篤子(2)フィリピナス総督府創設期の対外関係(序) : カトリック帝国と東・東 南アジア (1565-c.1650) (3)帝塚山学術論集 10 (4) 67-90 (5) 03/12

(1)弘末 雅士(2)港市と民族主義(3)一般：根本（編）(4) 131-147 (5) 04/03

(1)樑見 純生(2)元代のマラッカ海峡：通路か拠点か(3)東南アジア：歴史と文化 33 (4) 100-118 (5) 04/05

(1)牧田 りえ(2)農村土地なし層の発生メカニズムを追って(3)国際開発研究 12(2) (4) 157-174 (5) $03 / 11$

(1)宮治 一雄(2)イスラーム世界の民衆運動と民主化(3)一般：私市，栗田（編）(4) 1-28 (5) $04 / 01$

(1)向山 英彦(2)中国の経済発展とアジア分業体制の再編成(3)一般：日本中小企業学会 (編) (4) 31-44 (5) 04/06

(1)矢作 敏行(2)新たな歴史的段階を迎えた東アジアの流通(3)一般：矢作（編) (4) 1-22 (5) $03 / 11$

(1)八幡 成美(2)アジアの雇用政策(3)一般：一橋大学経済研究所経済制度研究センター (編) (4) 15-54 (5) 03/12

(1)山本 克也(2)世界銀行の福祉政策：東南アジアの年金政策を中心に(3)一般：大沢 (編) (4) 221-247 (5) 04/06

(1)吉野 文雄(2)A S E A Nの域外経済関係：中国とインド(3)海外事情 52(3)（拓殖大 学) (4) $46-62$ (5) $04 / 03$

(1)吉野 文雄(2)A S E A N・中国貿易の現状(3)海外事情 52(9) (拓殖大学) (4) 87-98 (5) 04/09

(1)米田 公丸(2)アジア諸国に展開する日系製造業にみる文化変容(3)アジア文化研究所 研究年報 38 (東洋大学) (4) 1(166)-8(159) (5) 04/02 


\section{〈インドネシア〉}

(1)青木 武信(2)現代インドネシアにおける社会変革と大衆芸能：スハルト新秩序体制 から「改革の時代」へのジャワ芸人のサバイバル(3)間科学研究 1 (日本大学) (4) 52-72 (5) 04/03

(1)青山 亨(2)インドネシアにおけるリベラル派イスラームの新思潮：ウリル・アブシ ヤル・アブダラのコンパス紙論説をめぐって(3)東南アジア学 9 (東京外国語大学)

(4) 24-41 (5) 04/03

(1)青山 亨(2)ギアツの『ジャワの宗教』とイスラームへの視点(3)総合文化研究ブック レット 4 (東京外国語大学) (4) 10-16 (5) 04/10

(1)石井 和子(2)パンチャシラ（インドネシア国家五原則）の第一原則：「唯一なる神 性 Ketuhanan Yang Maha Esa」の時空性(3)一般：根本（編）(4) 209-228 (5) 04/03 (1)伊藤 眞(2) Haji Tour under the Late New Order Regime in Indonesia: South Sulawesi Case (3) Toh Goda, ed. Postcolonialism and Local Politics in Southeast Asia (Quezon City: New Day Publishers) (4) 245-268 (5) 03/11

(1)伊藤 眞(2)カッサルの華人について (覚え書き) (3)人文学報 349 (東京都立大学) (4) 45-66 (5) 04/03

(1)岩本 陽一(2)ユドヨノ次期政権の挑戦(3)海外事情 52(10)（拓殖大学）(4) 36-48 (5) $04 / 10$

(1)植村 泰夫(2) The Depression and the Sugar Industry in Surabaya (3) Hiroshima Interdisciplinary Studies in the Humanities 3 (広島大学) (4) 1-54 (5) 04/03

(1)大形 里美(2)インドネシアの女性運動とジェンダーの主流化：女性 NGO の果たし た役割(3)一般：田村，織田（編）(4) 185-234 (5) 04/02

(1)太田 淳(2)'Traditional' versus 'Modern' Administrative Concepts: Dutch Intervention and its Results in Rural Banten (3) Itinerario 27(2) (Leiden University)(4) 61-85 (5) 03/11

(1)尾村 敬二(2)インドネシアにおけるソーシャル・セーフティネット形成政策(3) 般：一橋大学経済研究所経済制度研究センター(編) (4) 155-192 (5) 03/12

(1)加藤 剛(2)現代インドネシアの文化政策と地域アイデンティティ:リアウ州のムラ 工化の政治過程(3)一般：加藤（編）(4) 371-459 (5) 04/10

(1)金沢 朱美(2)インドネシア語話者におけるコード切り替えの様相について：書簡を 中心に(3)目白大学人文学研究 1 (4) 110-102 (5) 04/07

(1)川村 晃一(2) 2004 年アジアの選挙 インドネシア大統領選挙第 1 回投票：組織の 選挙とイメージの選挙(3)アジ研ワールド・トレンド 109 (4) 32-35 (5) 04/10

(1)北村 恵子(2)インドネシアにおけるシャリーア金融機関普及の背景：ジョクジャカ ル夕特別州の事例(3)国際開発研究フォーラム 27 (名古屋大学) (4) 17-35 (5) 04/08

(1)後藤 乾一(2)初期インドネシア独立革命と日本外交官：斎藤鎮男「報告書」をめぐ って(3)アジア太平洋討究 6 (早稲田大学) (4) 73-85 (5) 04/06

(1)小林 和夫(2)インドネシアにおける「伝統」の実践とポリティクス：新秩序体制下 
のゴトン・ロヨン（相互扶助）と都市住民組織 RT/RW の夜警をめぐって(3)社会学 評論 55(2)(4) 98-114 (5) 04/10

(1)小林 和夫(2)ゴトン・ロヨンが制度化されるとき：ジャカルタにおける住民組織 RT/RKの整備過程 (1954～1955年) (3)東南アジア：歴史と文化 33 (4) 26-58(5)04 $/ 05$

(1)小林 寧子(2)インドネシアのイスラーム伝統派の思想革新：アブドゥルラフマン・ ワヒドの思想形成の軌跡(3)一般：小松，小杉（編）(4) 239-274 (5) 03/12

(1)佐々木 拓雄(2)戸惑いの時代と「イヌル現象」大衆文化の観点からみたインドネシ ア・ムスリム社会の動態(3)東南アジア研究 42(2) (4) 208-230 (5) 04/09

(1)貞好 康志(2)インドネシア〈華人〉女性の個人史：マ・ニオからの考察（後編）(3) 近代 93 (神戸大学) (4) 1-17 (5) 04/05

(1)貞好 康志(2)ジャワで〈華人〉をどう識るか：同化政策 30 年後の後で(3)一般：加藤 (編) (4) 61-92 (5) 04/10

(1)常 杪, 井村 秀文(2)アジアの都市環境インフラ整備における国際開発機関・ ODA の新たな役割：官民協力体制構築への支援(3)国際開発研究 12(2) (4) 29-44 (5) $03 / 11$

(1)白石 隆(2)総説：アジアの選挙,インドネシアの選挙(3)国際問題 535 (4) 2-16 (5) 04/ 10

(1)新谷 正彦(2)インドネシアの社会会計行列から見た所得格差の推移(3)西南学院大學 經濟學論集 39(1) (4) 193-233 (5) 04/06

(1)新谷 正彦(2)インドネシア経済危機における所得分布の変化：社会会計行列からの 接近(3)西南学院大學經濟學論集 39(2) (4) 81-131 (5) 04/09

(1)杉島 敬志(2)口承史のポリフォニー：東インドネシア，中部フローレス，タナ・リ セの事例から(3)文化人類学研究 4 (早稲田大学) (4) 19-37 (5) $03 / 12$

(1)鈴木 恒之(2)あるべき歴史像を求めて：独立後インドネシア歴史学界の模索(3) 一 般：根本 (編) (4) 191-207 (5) 04/03

(1)鈴木 良枝(2)インドネシア・バリ島におけるガムラン音楽の創作活動風景(3)ムーサ 5 (沖縄県立芸術大学) (4) 25-33 (5) 04/03

(1)田子内 進(2)インドネシアのポピュラー音楽・ダンドゥットの発展：イヌル現象を 読み解く(3)年報地域文化研究 7 (東京大学) (4) 261-286 (5) 04/03

(1)利光 正文(2)インドネシアにおけるムスリム女性のイスラーム改革運動に関する覚 書：アイシャーを事例として(3)史学論叢 34（別府大学）(4) 64-70 (5) 04/03

(1)富尾 武弘(2)ジャワ元寇再考(3)攝大人文科学 12 (攝南大学) (4) 69-91 (5) 04/09

(1)豊田 和規(2)資料・ノート パラマヨガ：宮廷詩人ロンゴワルシトの「ジャワ神統 記」(3)南方文化 30 (4) 193-210 (5) 03/11

(1)内藤 耕(2)ジャカル夕南部の市場（いちば）における常設店商人の構成：03 年 8 月 のL市場の調査をもとに(3)文明研究 22 (東海大学) (4) 55-72 (5) 04/03

(1)橋 広冶(2)インドネシアにおけるジュマ・イスラミヤ問題(3)国際問題 528 (4) 67-78 
(5) $04 / 03$

(1)平尾 和洋, 高尾 克樹, 瀬戸口 健, 長谷川 豪(2)インドネシア・ジョグジャカ ルタ市のロモ・マゴン・カンポンの居住環境改善経過に関する考察(3日本建築学会 計画系論文集 574 (4) 105-112 (5) 03/12

(1)深尾 康夫(2)地方分権化時代における援助実施体制の模索：西ジャワ州ブカシ・カ ラワン 2 県における地方自治体と工業団地をめぐる状況から(3)インドシア：石田 (編) (4) 227-255 (5) 04/03

(1)舟田 京子(2)インドネシアにおける啄木受容(3)国文学：解釈と鑑賞 69(2) (4) 143147 (5) 04/02

(1)へイマンス・ファン・アンローイ (著), 深見 純生（訳）(2)翻訳 シアク王国誌 (1) 歴史的序論(3)国際文化論集 30（桃山学院大学） (4) 131-159 (5) 04/07

(1)本台 進(2)経済発展と産業間労働力移動：インドネシアの労働力移動に関する分析 への含意(3)国際協力論集 11(2)（神戸大学）(4) 101-114 (5) 03/12

(1)増原 綾子(2)インドネシア・スハルト体制初期の大統領と暫定国民協議会(3)アジア 経済 45(10) (4) 2-23 (5) 04/10

(1)宮本 基杖(2)熱帯林の農地転換：人口増加・道路建設・移住事業の影響：インドネ シア・スマトラ島におけるゴム栽培農村の事例(3)林業経済研究 49(3)(4) 21-30 5) 03/ 11

(1)村井 吉敬(2)インドネシアの地域騒乱：宗教・民族紛争なのか(3)一般：私市, 栗田 (編) (4) 197-222 (5) 04/01

(1)森下 明子(2)スハルト体制崩壊後のインドネシア政治エリート：1999 年総選挙に よる国会議員とはどのような人たちか(3)東南アジア研究 41(3) (4) 361-385 (5) 03/12

(1)山本 郁郎(2)インドネシア中小企業の成長戦略と産地の企業ネットワーク (3)金城学 院大学論集 社会科学編 46 (4) 51-80 (5) 04/03

(1)山本 信人(2)排除された市民の再構成：インドネシア国家と華人系住民(3)一般：関 根・山本 (編) (4) 231-257 (5) 04/06

(1)横山 豪志(2)イドネシアの民主化についての一考察：「政治 3 法」の制定過程を 中心に(3)筑紫女学園大学紀要 16 (4) 175-195 (5) 04/01

\section{〈カンボジア〉}

(1)天川 直子(2)カンボジアの人種主義：ベトナム人住民虐殺事件をめぐる一考察(3)一 般：武内 (編) (4) 109-145 (5) 03/12

(1)石澤 良昭(2)なぜアンコール王朝末期に仏像の大量破壊が起こったか(3)アンコール 遺跡を科学する 10 (上智大学) (4) 1-10 (5) 03/12

(1)石澤 良昭(2)クメール文化の至宝・アンコール遺跡(3)季刊民族学 108 (4) 1-50 (5) $04 / 04$

(1)伊藤 友美(2)カンボジア仏教：二つの共産主義政権の経験と社会への関わり(3)国際 文化学 10 (神戸大学) (4) 17-35 (5) 04/03 
(1)植村 和代(2)カンボジア (クメール) の織物文化 7 ：日本近世の高機とカンボジア の織機(3)は 11 (帝塚山短期大学) (4) 102-116 (5) 04/03

(1)北川 香子(2)コムポン・チャーム理事管区における公教育制度の導入：理事官府定 期報告書より(3)東南アジア：歴史と文化 33 (4) 59-80 (5) 04/05

(1)佐藤 奈穂(2)農村における女性地帯に対する親族と共同体の役割：カンボジアシェ リムアップ州タートック村を事例として(3)龍谷大学経済学論集 43(5) (4) 53-72 (5) $04 / 03$

(1)竹下 守夫(2)法整備支援の現状と課題：カンボディア民事訴訟法典起草支援の経験 を踏まえて(3)比較法文化：駿河台大学比較法研究所紀要 12 (4) 27-48 (5) 04/03

(1)永田 伸吾(2)カーター政権とカンボジア国連代表権問題：人権外交の限界と国際政 治(3)国際関係学研究 17 (東京国際大学) (4) 127-144 (5) 04/02

(1)野澤 知弘(2)カンボジアの華人社会 : 僑生華人と新客華僑の共生関係(3)アジア経済 45(8) (4) 63-99 (5) 04/08

(1)服部 博紀, 西本 真一, ソ・ソクンテリー, 中川 武(2)カンボジア, アンコー ル・トム城門の建造過程(3)日本建築学会計画系論文集 575 (4) 175-182 (5) 04/01

(1)村嶋 英治(2)ナショナル化に吞み込まれるエスニシティ：クメール人とは誰か？(3) アジア太平洋討究 6 (早稲田大学) (4) 55-71 (5) 04/06

\section{くシンガポール〉}

(1)奥村みさ(2)都市国家における心象風景：シンガポールの都市再開発にみるポストコ ロニアル・ナショナリズム(3)中京大学国際英語学部紀要 5 (4)17-34(5) 04/09

(1)桑島 昭(2)世界大戦の性格と「地域」の視点：シンガポールにおけるインド兵の反 乱(1915)（特集 歴史としてのグローバリゼーション) (3)Ex Oriente 10 (大阪外国語 大学) (4) 21-43 (5) 04/02

(1)篠崎 香織(2)シンガポール華人商業会議所の設立（1906 年）とその背景：移民によ る出身国での安全確保と出身国との関係強化(3)アジア研究 50(4) (4) 38-54 (5) 04/10 (1)田中 雅一(2)宗教による支配・抵抗から主体化へ：スリランカとシンガポールに見 る夕ミル人たちの儀礼経験をめぐって(3)一般：池上（編）(4) 163-190 (5) 04/07

(1)田村 慶子(2)シンガポールにおけるジェンダーの主流化と NGO：メリトクラシー の厚い壁(3)一般：田村, 織田 (編) (4) 117-146 (5) 04/02

(1)田村 慶子(2)リー・シェンロン時代の幕開けと課題：偉大な父の光と影の下で(3)海 外事情 52(10)（拓殖大学）(4) 21-35 (5) 04/10

(1)中村 みゆき(2)シンガポール政府持株会社テマセク社の株式売却に関する考察(3)ア ジア研究 50(4) (4) 55-78 (5) 04/10

(1)西尾 圭一郎(2)シンガポールにおける多国籍企業の進出と基軸通貨ドル(3)經營研究 55(1)（大阪市立大学）(4) 211-234 (5) 04/05

(1)邊土名 朝邦(2)シンガポール文化事情点描(3)西南学院大学国際文化論集 18(2) (4) 257-269 (5) $04 / 02$ 


\section{〈タ イ〉}

(1) Christian Daniels (2)夕イ族は国王の系譜をかく描けり：ハーイ・ロンに対する歴 史記憶(3)アジア遊学 67 (4) 52-71 (5) 04/09

(1) Masuda Erika (2) The Last Siamese Tributary Missions to China, 1851-1854 and the "Rejected" Value of Chin Kong (3) Wang Gungwu, Ng Chim-kong (ed.), Maritime China in Transition 1750-1850. Wiesbaden: Harrassowitz Verlag (4) $33-42$ (5) 2004

(1) Somchai Chakhatrakan (2)夕イ農業の課題と農業教育 (課題 熱帯開発途上国にお ける農業教育の役割：社会開発の基盤活動)(3)熱帯農業 48 (EXTRA 1) (4) 144-146 (5) $04 / 03$

(1)浅見 靖人(2)夕イにおけるソーシャル・セーフティネット(3)一般：一橋大学経済研 究所経済制度研究センター(編) (4) 193-225 (5) 03/12

(1)足立 文彦(2)一村一品運動と現代アジア：大分県と北夕イ地域の現地調査から(3)一 般：日本中小企業学会（編）(4) 17-30 (5) 04/06

(1)飯島 明子(2)夕イ国ヤソートーン県ワット・マハータート所蔵貝葉写本について： 「夕ム文字写本文化圈」の事例(3)一般：「史資料ハブ地域文化研究拠点」総括班（編） (東京外国語大学) (4) 108-130 (5) 04/03

(1)石井 米雄(2) A Note on the Identification of a Group of Siamese Port-polities along the Bay of Thailand (3) Memoirs of the Research Department of The Toyo Bunko（東洋文庫）61 (4) 75-82 (5) 2003

(1)宇都宮 由佳, 高橋 ユリア, スィワナーソン・パタニ（他）(2)北夕イの若者の食 行動について：1992 年と 2001 年(3)大妻女子大学家政系研究紀要 40 (4) 39-45 (5) 04/ 03

(1)榎本 啓一郎(2)海外事業投資と外資規制：タイ国「外国人事業法」に関する考察(3) 福岡大学商学論叢 49(1) (4) 123-158 (5) 04/06

(1)王 柳蘭(2)国境を越える「雲南人」：北夕イにおける移動と定着にみられる集団の生 成過程(3)ジア・アフリカ言語文化研究 67 (東京外国語大学) (4) 211-262 (5) 04/03

(1)岡部 真由美(2)現代夕イにおける仏教寺院の HIV/AIDS ケア活動の社会的位置づ け：フアリン寺を事例として(3)ぽぷるす 3 (神戸大学) (4) 1-38 (5) 04/03

(1)柿崎 一郎(2)「開発」の時代の夕イ鉄道 1958-1973 年 : 道路優先政策下での対応(3) アジア・アフリカ地域研究 3 (京都大学) (4) 140-173 (5) 03/11

(1)柿崎 一郎(2)夕イの鉄道と米輸送 1941-1957 年：輸送力不足と東北部(3)東南アジ ア研究 42(2) (4) 157-187 (5) 04/09

(1)片岡 樹(2)領域国家形成の表と裏：冷戦期タイにおける中国国民党軍と山地民(3)東 南アジア研究 42(2) (4) 188-207 (5) 04/09

(1)片山 隆裕(2)夕イにおける開発パラダイムの転換とエイズ対策：チェンマイ県サン パトン郡の事例を中心に(3)西南学院大学国際文化論集 18(2) (4) 153-176 (5) 04/02

(1)加藤 雅信(2)「原初的所有権」発生の形態：タイ北部山岳少数民族の所有権・入会 
権のルポタージュ的スケッチからくI 民事法学の基礎理論〉（伊藤高義教授退官記 念論文集）(3)名古屋大學法政論集 201 (4) 27-140 (5) 04/03

(1)川野 美砂子(2)「東洋の自由の地」：世紀転換期アメリカ人宣教師の見た北夕イ(3)総 合教育センター紀要 24（東海大学) (4) 69-90 (5) 04/03

(1)河村 雅美(2)サリット時代 (1958-1963 年) のメディアにみられる夕イの開発イメ ージ：「開発」の精神とその解釈をめぐって(3)東南アジア：歴史と文化 33 (4) 81-99 (5) $04 / 05$

(1)木村 雄一(2)人的資本蓄積に対する大都市の役割：バンコク労働市場についての実 証(3)国際開発研究 13(1) (4) 51-69 (5) 04/06

(1)新谷 正彦(2)夕イ国農家家計の合理的行動：スパンブリ県の水稲生産の事例(3)西南 学院大學經濟學論集 38(3) (4) 163-186 (5) 04/01

(1)新谷 正彦(2)夕イ国農家家計の合理的行動と技術効率：スパンブリ県の水稲生産の 事例(3)西南学院大學經濟學論集 38(4) (4) 209-243 (5) 04/02

(1)杉山 晶子(2)シャムにおける公定ナショナリズムと新聞上の言論 (1910-25 年) (3) 一般：根本 (編) (4) 61-88 (5) 04/03

(1)鈴木 規之(2)異文化との出逢いからの問題意識：タイ地域研究の場合(3)一般：大谷 (編) (4) 197-214 (5) 04/03

(1)高橋 正樹(2) 90 年代のタイ：グローバリゼーションとタイ政治の変動(3)アジ文 化研究所研究年報 38 (東洋大学) (4) 69(98)-78(89) (5) 04/02

(1)田中 厚彦(2)夕イ国における法制度の近代化(3)東洋学園大学紀要 12 (4) 85-97 (5) $04 / 03$

(1)田辺 和子, 清水 洋平(2)パンニャーサジャータカ貝葉写本タイ王室コレクション 報告(3)パーリ学仏教文化学 17 (4) 139-146 (5) 03/12

(1)新見 道子(2)変容する夕イ・バンコクの低所得者層：1980 年代後半に形成された 集落の全戸調查から(3)一般：山脇，丸山，柴田（編）(4) 217-257 (5) 04/07

(1)西本 陽一(2)周辺少数民族におけるポップス：北タイ・キリスト教徒ラフにおける アイデンティティ形成の一側面(3)論集 行動科学・哲学編 24 (金沢大学) (4) 27-70 (5) $04 / 03$

(1)西本 陽一(2)山の民から少数民族へ：タイ北部・ラフの山地民意識とその変化(3)地 学雑誌 113(2) (4) 283-293 (5) 04/04

(1)橋本 泰子(2) 20 世紀初頭夕イにおける男女規範をめぐるイデオロギーの再編成(3) 社会学研究科紀要 4(四国学院大学) (4) 1-18 (5) 04/03

(1)馬場 雄司(2)夕イ族「源流」へのまなざし：経済成長とグローバリゼーションの中 で(3)アジア遊学 57 (4) 126-134 (5) 03/11

(1)林 行夫(2)隠蔽される身体と「紏」の所在：制度宗教の表象と夕イ仏教危機論(3) 般：池上（編）(4) 215-243 (5) 04/06

(1)林 行夫(2)活きる周縁, 摇らぐ中心：タイ系民族の国境域での仏教実践の動態(3) 般：加藤 (編) (4) 143-200 (5) 04/10 
(1)船津 鶴代(2)夕イの中等教育拡大：その「階層化」された普遍化(3)一般：米村（編） (4) $241-274$ (5) $03 / 12$

(1)松田 博幸, 大森 豊裕, 川口 茂博, 小西 正康(2)夕イの水上住宅：その 2 杭上 住宅(3)近畿大学工学部研究報告 37 (4) 111-120 (5) 03/12

(1)松本 淳(2)日本の教育再生へのアプローチ：タイの教育との比較を中心に(3)學苑 765 (昭和女子大学) (4) 14-26 (5) 04/06

(1)元村 直靖(2)夕イの医療保健制度(3)大阪教育大学紀要 第 III 部門 自然科学 - 応 用科学 52(2) (4) 287-296 (5) 04/02

(1)矢野 秀武(2)夕イの上座仏教と公共宗教(3)一般：池上（編）(4) 51-74 (5) 04/07

(1)ランダル・シャノン，ルジルタナ・マンドハチタラ(2)タイ小売競争の加速と反動(3) 一般：矢作 (編) (4) 227-248 (5) 03/11

\section{〈東ティモール〉}

(1)大河内 美香(2)貨幣用金事件規則の適用基準にかかる覚書：一九九五年国際司法裁 判所・東ティモール事件判決を中心に(3)中央学院大学法学論叢 17(1/2) (4) 127-152 (5) $04 / 03$

\section{〈ビル マ〉}

(1) Takatani Michio (2) Shan Construction of Knowledge (3) Texts and Contexts in Southeast Asia (4) part II 52-66 (5) 03/12

(1)イェン・イェン(2)現代ビルマ社会におけるカルマ思想：人々のカルマに対する解釈 の事例から(3)国際文化学 10 (神戸大学) (4) 1-15 (5) 04/03

(1)池田 正隆(2)サーサナーランカーラ・サーダン (Sāsanālañkāra cātam) : ビルマ の仏教史に関する伝承の記録（10）(3)仏教研究 32 (4) 133-178 (5) 04/03

(1)奥平 龍二(2)「通史」の成立と変容：ビルマにおける前近代史研究(3)一般：根本 (編) (4) 149-166 (5) 04/03

(1)熊田 徹(2) 1962 年ミャンマー軍事クーデターの背景要因としての外部介入：米国 国務省外交記録を中心として見たその経緯(3)外務省調査月報 3 (4) 23-55 (5) 03/12

(1)栗田 匡相, 岡本 郁子, 黒崎 卓 (他) (2)ミャンマーにおける米増産至上政策と 農村経済：8力村家計調査データによる所得分析を中心に(3)アジア経済45(8) (4)2 -37 (5) $04 / 08$

(1)斎藤 照子(2)ナショナリズムと経済思想：ビルマの国民経済構想をめぐって(3) 般：根本 (編) (4) 39-59 (5) 04/03

(1)斎藤 照子(2)ビルマ・アーカイブス小史：経蔵から公文書館へ(3)歴史学研究 789 (4) 13-23 (5) 04/06

(1)佐々木 達夫, 野上 建紀, 佐々木 花江 (2)ミャンマー古窯跡踏査と採集陶磁器 (3)金沢大学考古学紀要 27 (4) 147-246 (5) 04/06

(1)澤田＼cjkstart英夫(2)ビルマ語の語類(3)アジア・アフリカ文法研究 32 (東京外国語大学) 
(4) $57-59$ (5) $04 / 03$

(1)中西 嘉宏(2)未完の党=国家：ネー・ウィンとビルマ社会主義計画党(3)東南アジア 研究 41(3) (4) 330-360 (5) 03/12

(1)根本 敬(2)「英系ビルマ人」が「ビルマ国民」になるとき：血統主義, 出生地主義 (3)一般：根本 (編) (4) 89-110 (5) 04/03

(1)根本 敬(2)ビルマ・アラカン州におけるロヒンギャー問題に関する予備的考察(3)そ の他：荒井 (編) (4) 191-208 (5) 04/03

(1)根本 敬(2)現代ミャンマーの政治をどう見るか：軍政下の政治過程と民主化問題(3) 国際問題 535 (4) 58-77 (5) 04/10

(1)水野 敦子(2)ミャンマーと中国の経済協力関係(3)季刊経済研究 27 (1 ・ 2) (大阪市 立大学) (4) 175-200 (5) 04/09

(1)森 兆立(2)19世紀ビルマにおける王権と仏教：ミンドン王を中心に（修士論文要旨） (3)龍谷大学大学院文学研究科紀要 25 (4) 325-328 (5) 03/12

(1)數 司郎(2)ミャゼディ碑文における古ビルマ語 $(\mathrm{OB})$ 覚書（特集 ことばの変化） (3) Ex Oriente 11 (大阪外国語大学) (4) 59-100 (5) 04/09

\section{〈フィリピン〉}

(1) Kawashima Midori (2) Explanatory Notes in the Maranao Petitions: Letters of Haji Bogabong, 1935 (3)上智アジア学 21 (上智大学) (4) 219-232 (5) 03/12

(1)青山 和佳(2)フィリピン・ダバオ市のバジャウ移民のキリスト教受容：生活水準改 善への微細な投企? (3)経済学論集 69(4)（東京大学) (4) 57-92 (5) 04/01

(1)安食 和宏(2)フィリピン・レイテ島の農村集落からの人口移動について(3)人文論 叢：三重大学人文学部文化学科研究紀要 21 (4) 17-34 (5) 04/03

(1)池端 雪浦(2)明治期日本人のフィリピンへのまなざし(3)フィリピン：池端，ユー・ ホセ (編) (4) 3-33 (5) 04/02

(1)伊藤 裕子(2)戦後アメリカの対フィリピン軍事政策と日本要因 1945～1951年(3)フ イリピン：池端，ユー・ホセ（編）(4) 327-366 (5) 04/02

(1)内山 史子(2)フィリピンにおける国民形成と宗教教育：公立学校における宗教教育 をめぐる 1938 年の論争についての一考察(3)一般：根本（編）(4) 1-22 (5) 04/03

(1)小瀬木 えりの(2)フィリピン産織物ニピスの文化的意味変容をめぐって(3)一般：加 藤（編）(4) $321-370$ (5) $04 / 10$

(1)川島 緑(2)南部フィリピン紛争と市民社会の平和運動：2000 年の民間人虐殺事件 をめぐって(3)一般：武内（編）(4) 409-449 (5) 03/12

(1)川島 緑(2)南部フィリピン・ムスリム社会の山賊と民衆：「恐るべきラナオの王」 の反乱(3)一般：私市, 栗田 (編) (4) 101-126 (5) 04/01

(1)川島 緑(2) 1930 年代フィリピン・ラナオ州におけるイスラーム改革運動：カーミ ロル・イスラーム協会設立をめぐって(3)一般：根本 (編) (4) 229-254 (5) 04/03

(1)川島 緑(2)史料紹介：南部フィリピン・イスラーム地域のジャウィ史料(3)歴史と地 
理 576 ：世界史の研究 200 (4) 49-55 (5) 04/08

(1)川中 豪(2)フィリピンの大統領制と利益調整(3)一般：日本比較政治学会（編）(4) 157-180 (5) 04/06

(1)川中 豪(2)フィリピン政治と民主主義(3)一般：関根・山本（編）(4) 157-174 (5) 04/ 06

(1)川中 豪(2)政治不信か, 混乱への懸念か：2004 年フィリピン大統領選挙(3)国際問題 535 (4) $46-57$ (5) $04 / 10$

(1)後藤 美樹(2)フィリピンの住民自治組織・バランガイの機能と地域社会：首都圏近 郊ラグナ州村落の住民生活における役割(3)国際開発研究フォーラム 25（名古屋大 学) (4) 61-80 (5) 04/02

(1)小幡 壮(2)熱帯雨林の闇夜に響く物語り世界：タジャワンの狩猟詩歌 資料その 1 (3)国際関係・比較文化研究 2(2)（静岡県立大学) (4) 189-215 (5) 04/03

(1)菅谷 成子(2)スペイン領フィリピンにおける中国人統治：『異教徒の他者』から「ス ペイン国王の臣民」へ(3人文学論叢 5(愛媛大学) (4) 78-90 (5) 03/12

(1)鈴木 伸隆(2)米国植民地統治下におけるフィリピン・ミンダナオ島と管理される主 体としての「モロ」(3)歴史人類 32（筑波大学） (4) 119-165 (5) 04/03

(1)関 恒樹(2)低地フィリピン社会における主体・エイジェンシー・アイデンティテ 1：個に内在する力としてのドゥガン dungan の観念に注目して(3)史苑 64(2)（立 教大学) (4) 13-38 (5) 04/03

(1)田中 和彦(2)ルソン島北部における新石器時代稲出土遺跡の立地環境：カガヤン州, アンダラヤン遺跡の立地と河川の流路(3)環境情報研究 12（敬愛大学）(4) 29-43 (5) 04/04

(1)田中 和彦(2)遺跡速報 ルソン島北部, 鉄器時代貝塚の発掘調査: ラロ貝塚群, バ ガッグ I 貝塚の発掘調査(3)月刊考古学ジャーナル 520 (4) 34-38 (5) 04/09

(1)田巻 松雄(2)問題意識の希薄さと自分の原点を振り返る：フィリピンからホームレ ス・寄せ場へ(3)一般：大谷 (編) (4) 99-119 (5) 04/03

(1)ロサリナ・パランカ・タン (著), 中島 䁔（訳）(2)戦後のフィリピン・日本貿易関 係(3)フリピン：池端，ユー・ホセ(編) (4) 513-539 (5) 04/02

(1)知花 いづみ(2)政治基盤を固めた第 2 期アロヨ政権（2004 年アジアの選挙）(3) ジ研ワールド・トレンド 10(8) (4) 40-43 (5) 04/08

(1)グウェンドリン・R・テクソン (著), 中島 醸 (訳) (2)戦後日本の対フィリピン直 接投資: 傾向, 決定要因, 将来の日本・フィリピン関係への影響(3)フィリピン：池 端，ユー・ホセ (編) (4) 471-511 (5) 04/02

(1)寺田 勇文(2)日本のフィリピン占領とキリスト教会(3)フィリピン：池端, ユー・ホ 七(編) (4) 245-286 (5) 04/02

(1)寺見 元恵(2)1930年代の日本・フィリピン親善事業(3)フィリピン：池端，ユー・ホ セ (編) (4) 159-198 (5) 04/02

(1)永井 均(2)日本・フィリピン関係史に抢ける戦争犯罪問題：フィリピンの東京裁判 
参加をめぐって(3)フィリピン：池端，ユー・ホセ（編）(4) 289-326 (5) 04/02

(1)永井 博子(2)フィリピン村落工業における開発の失敗：人類学的視点からの試論(3) 史苑 64(2)（立教大学) (4) 39-63 (5) 04/03

(1)中野 聡(2)追悼の政治：戦没者慰霊をめぐる第二次世界大戦後の日本・フィリピン 関係史(3)フィリピン：池端，ユー・ホセ（編）(4) 367-408 (5) 04/02

(1)永野 善子(2)フィリピンのアジア間貿易と日本 1868 1941年(3)フィリピン: 池端, ユー・ホセ (編) (4) 81-120 (5) 04/02

(1)野沢 勝美(2)フィリピン電力産業自由化の構造(3)アジア研究所紀要 30 (亜細亜大 学) (4) 34-10 (5) $03 / 03$

(1)野沢＼cjkstart勝美(2)構造調整下フィリピンのソーシャル・セーフティネット(3)一般：一橋 大学経済研究所経済制度研究センター（編）(4) 103-154 (5) 03/12

(1)早瀬 晋三(2)アメリカ・フィリピン自由貿易体制下の日本商品とその取扱商：予備 的考察(3)フィリピン：池端，ユー・ホセ（編）(4) 121-155 (5) 04/02

(1)早瀬 晋三(2)米領下フィリピンの大衆消費日本商品：輸入統計資料分析(3)人文研究 55(2)（大阪市立大学）(4) 1-39 (5) 04/03

(1)葉山 アツコ(2)フィリピンにおける森林管理の 100 年：地域住民の位置づけをめぐ って(3)経済史研究 7(大阪経済大学) (4) 87-105 (5) 03/03

(1)マリア・ロサリオ・ピケロ・バレスカス (著), 高畑 幸 (訳) (2)1970年代以降の日 本におけるフィリピン人移民：その再構築に向けて(3)フィリピン：池端, ユー・ホ セ (編) (4) 583-619 (5) 04/02

(1)マリア・ロザリオ・ピケロ・バレスカス (著), 田巻 松雄, 大谷 美奈 (訳) (2)社 会問題の選択と問題意識の明確化：フィリピン社会と日本社会を越えて(3)一般：大 谷 (編) (4) 177-195 (5) 04/03

(1)ウィルフリド・ビリャコル夕 (著), 佐久間 美穂 (訳) (2)アキノ政権期およびラモ ス政権期におけるフィリピン・日本政治関係(3)フィリピン：池端, ユー・ホセ（編） (4) 621-657 (5) 04/02

(1)リカルド・T・ホセ (著), 中野 聡（訳）(2)信念の対決：「ラウレル共和国」と日 本の戦時外交関係 1943～1945年(3)フィリピン：池端，ユー・ホセ(編) (4) 199-243 (5) $04 / 02$

(1)森谷 裕美子(2)フィリピン・パラワン族社会におけるディワタ観念の変容(3)九州国 際大学国際商学論集 15(1) (4) 49-76 (5) 03/12

(1)森谷 裕美子(2)イゴロットとは誰か(3)九州国際大学国際商学論集 15(3) (4)57-90 (5) $04 / 03$

(1)矢野 秀徳(2)伝統的エリート民主主義の「復権なき復活」（4）：戦後フィリピン政治 体制変動に関する一試論(3)北大法学論集 54(5)（北海道大学）(4) 336-281 (5) 03/12

(1)矢野 秀徳(2)伝統的エリート民主主義の「復権なき復活」（5）：戦後フィリピン政治 体制変動に関する一試論(3)北大法学論集 55(1)（北海道大学）(4) 392-339 5) 04/05

(1)リディア・N・ユー・ホセ（著), 伊藤＼cjkstart裕子（訳）(2)フィリピン中立化問題をめぐ 
るフィリピン・アメリカ・日本三国関係 1900～1939年(3)フィリピン：池端，ユ 一・ホセ (編) (4) 35-79 (5) 04/02

(1)吉川 洋子(2)日本・フィリピンの出発外交：賠償実施，賠償借款交涉，通商航海条 約交渉 1956〜1963年(3)フィリピン：池端，ユー・ホセ（編）(4) 409-467 (5) 04/02 (1)吉野 文雄(2)アロヨ大統領の再挑戦(3)海外事情 52(10)（拓殖大学）(4) 49-60 (5) 04/ 10

(1)米村 明夫, 玉懸 光枝(2)フィリピンにおける初等教育発展：現状，規定要因の統 計的分析(3)一般：米村 (編) (4) 211-240 (5) 03/12

(1)テマリオ・C・リベラ (著), 伊賀 司 (訳) (2)援助の政治経済学：フィリピンにお ける日本のO D A 1971～1999年(3)フィリピン：池端，ユー・ホセ（編）(4) 541582 (5) $04 / 02$

\section{〈ベトナム〉}

(1)荒尾 美代(2)ベトナム中部における伝統的な白砂糖生産について：「覆土法」を中 心に(3)技術と文明 14(1) (4) 43-55 (5) 03/11

(1)内海 佐和子(2)ベトナム・ハノイ 36 通り地区の保存に関する研究：町屋の外観の 変容と課題(3)學苑 766 (昭和女子大学) (4) 156-162 (5) 04/07

(1)大橋 健一(2)植民都市におけるホテルに見る文化構築の動態：ベトナム・ダラット を事例として(3)立教大学観光学部紀要 6 (4) 39-44 (5) 04/03

(1)岡江 恭史(2)べトナム農村金融における集落の役割(3)農林水産政策研究 6 (4) 23-49 (5) $04 / 03$

(1)金子 由芳(2)市場経済化における法整備の比較考察：ベトナム・ロシア・中国（1） (3)国際協力論集 12(2)（神戸大学) (4) 15-44 (5) 04/10

(1)久保 文明(2)国内政治の変容と外交政策：とくに東アジアとの関連で(3)一般：久保, 赤木 (編) (4) 25-54 (5) 04/08

(1)黒澤 靖, 江頭 和彦(2)べトナム紅河流域の地水環境と農林業並びにそれらを巡る 今日の諸問題(3)熱帯農業 48(1) (4) 49-56 (5) 04/03

(1)小林 和彦(2)ヴェトナムの文廟について：ハノイ文廟とフエ文廟を通してのヴェト ナム儒教についての素描（坂出祥伸教授退休記念号）(3)関西大学中国文学会紀要 25 (4) 41-66 (5) 04/03

(1)佐々木 有道, 柳澤 雅之, 縄田 栄治, 桜谷 哲夫(2)ベトナム北西部山岳地帯に おけるドイモイ以降の農業変容：Son La 省 Moc Chau県の事例(3)熱帯農業 48 (EXTRA 1) (4) 99-100 (5) 04/03

(1)佐藤 安信, Tran Han Giang, 菅原 鈴香(2)客員研究員中間報告 法・貧困・ジ エンダー: ベトナムにおける法多元主義と正義へのアクセス(3)アジア女性研究 13 (4) $98-100$ (5) $04 / 03$

(1)嶋尾＼cjkstart稔(2) 20 世紀初頭ベトナムの通史について(3)一般：根本（編）(4) 167-189 (5) $04 / 03$ 
(1)白石 昌也(2)ベトナムの社会主義体制(3)一般：関根・山本 (編) (4) 175-200 (5) 04/06

(1)白石 昌也, 伊東 淳一(2)ホーチミン市における日本商工会の設立と初期の活動(3) アジア太平洋討究 6 (早稲田大学) (4) 19-53 (5) 04/06

(1)菅原 鈴香(2)法と社会：異なる規範とパワーの狭間で：ベトナム・ホアビンダム湖 周辺保存林地区に住む人々の土地使用権獲得プロセスと「貧困」及び「森林破壊」 への示唆(3) Discussion paper 123 (4) 123 (5) 04/02

(1)高岡 弘幸(2)消費社会のエスノグラフィー:ベトナムの「sieu thi」と中国の「便利 店」(3)高知女子大学文化論叢 5(4) 4-16 (5) 03/03

(1)高田 洋子(2)法と植民地主義：ベトナムにおけるフランス近代法導入をめぐる一考 察(3)敬愛大学国際研究 12 (4) 1-22 (5) 03/11

(1)中野 亜里(2)べトナム：二元的構造における政治変動・政治発展(3)一般：岸川, 岩 崎（編）(4) 179-199 (5) 04/06

(1)西村 昌也(2)世界の発掘調査 西から東から：ベトナム(3)文化遺産の世界 11 (4) 20-21 (5) 03/11

(1)野口 博史, 中馬 祥子(2)北部べトナム一集落における市場経済化の諸特性：多元 性と平等性，1999-2000 年(3)国学院経済学 52(1) (4) 121-148 (5) 04/02

(1)箱木 且澄(2)東南アジアの持続的発展を考える(2)ベトナムの経済発展と直接投資・ 環境問題：ベトナムの産業を担う人々(3)広島経済大学経済研究論集 27 (2)(4) 49-75 (5) $04 / 09$

(1)浜野 隆(2)初等教育普遍化に向けての政策課題と国際教育協力：ベトナムの事例(3) 国際教育協力論集 7(2)（広島大学） (4) 39-53 (5) 04/10

(1)藤本 博(2)アメリカ合衆国と戦争：朝鮮戦争，ヴェトナム戦争を中心に(3)一般：木 畑（編）(4) 107-155 (5) 04/01

(1)村井 泰廣(2)アメリカ合衆国におけるべトナム難民の地理的定住分布とその特徴(3) 環太平洋・アイ又文化研究 4（苫小牧駒澤大学） (4) 71-98 (5) 04/03

(1)八尾 隆生(2)藍山蜂起と『藍山実録』編纂の系譜：早咲きのヴェトナム「民主主義」 (3)歷史学研究 789 (4) 42-51 (5) 04/06

(1)八尾隆生(2)『大南一統志』編纂に関する一考察(3)広島東洋史学報 9 (4) 1-35 (5) 04/ 12

\section{〈マレーシア〉}

(1) Nor Hashimah Jalaluddin (2) The Changing Language Policy in Malaysia: Facing New Challenges (3)アジア太平洋論叢 14 (4) 31-54 (5) 04/08

(1)石川 登(2)歴史のなかの民族境界：ボルネオ島西部国境社会における村落と国家(3) 一般：加藤 (編) (4) 22-60 (5) 04/10

(1)市川 哲(2)マレーシア華人の国際的な活動領域に見るローカルなネットワーク：パ プアニューギニアにおける活動を事例として(3)華僑華人研究 1 (4) 58-77 (5) 04/09

(1)鵜沢 洋志(2)マレーシア語の主語に関する一考察(3)言語・地域文化研究 10 (東京 
外国語大学) (4) 141-155 (5) 04/03

(1)奥島 美夏(2) Ethnic Background of the Tidung: Investigation of the Extinct Rulers of Coastal Northeast Borneo (3)上智アジア学 21（上智大学） (4) 237-264 (5) $03 / 12$

(1)小野澤＼cjkstart純(2)アブドラ新政権下のマレーシア(3)海外事情 52(10)（拓殖大学）(4) 220 (5) $04 / 10$

(1)金子 芳樹(2)マハティール体制の確立過程：マレーシアにおける政治体制とリーダ ーシップ(3)一般：関根・山本（編）(4) 201-230 (5) 04/06

(1)國分 圭介(2)マレーシアにおける産業クラスターと人口労働 1970～2000年 (3)国際 開発研究 13(1) (4) 71-81 (5) 04/06

(1)田村 慶子(2)マレーシアの NGO とジェンダーの主流化：エスニックな分断を超え て(3)一般：田村，織田（編）(4) 83-114 (5) 04/02

(1)角田 典子(2)マレーシアの「国家語」とその変容(3) STUDIUM 31 (大阪外国語大 学) (4) $187-196$ (5) 04/04

(1)坪井 祐司(2)英領期マラヤにおける「マレー人」枠組みの形成と移民の位置づけ： スランゴル州のプンフルを事例に(3)東南アジア：歴史と文化 33 (4) 3-25 (5) 04/05

(1)アンジェリン・テイ(2)外資攻勢で変わるマレーシア小売市場(3)一般 : 矢作 (編) (4) 249-270 (5) 03/11

(1)鳥居 高(2)マレーシアの政治体制と二つの民衆運動(3)一般：私市，栗田 (編) (4) 179 -196 (5) 04/01

(1)鳥居 高(2)多種族国家マレーシアにおける連立政党の仕組みと限界：1999 年総選 挙における国民戦線(3)一般：日本比較政治学会（編）(4) 181-213 (5) 04/06

(1)長津 一史(2)〈正しい〉宗教の政治学：マレーシア国境海域におけるイスラームと 国家(3)一般：加藤（編） (4) 245-294 (5) 04/10

(1)西尾 寛治(2)マレー世界における契約：商業的契約と政治的契約(3)一般：三浦，岸 本, 関本 (編) (4) 141-161 (5) $04 / 02$

(1)箱木 眞澄(2)東南アジアの持続的発展を考える (1) マレーシアの経済発展と直接 投資・環境問題(3)広島経済大学経済研究論集 26(4) (4) 89-101 (5) 04/03

(1)原 百年(2)マレーシアの民族間対立：エリートレベルと民衆レベルの意識的差異(3) 山梨学院大学一般教育部論集 25 (4) 57-72 (5) 03/01

(1)多谷 鋭(2) 60 年代マラヤ華人社会における文学史創出期について(3)白山人類学 7 (4) $103-113$ (5) $04 / 03$

(1)松井 範惇, Lee Ming Tai (2) Evaluation of Involuntary Resettlement of Squatters in Malaysia : A Case Study of Malayan Railway Improvement Project (3)国 際開発研究 12(2) (4) 175-191 (5) 03/11

(1)モハメド・ユソフ・イスマイル (著), 岩田 晶子（訳）(2)イスラーム国家マレーシ アに見る仏教徒シャム人のアイデンティティ(3)一般：加藤 (編) (4) 295-320 (5) 04/10 (1)吉村 真子(2)マレーシアにおけるソーシャル・セーフティネット(3)一般：一橋大学 
東南アジア 一 歴史と文化 - No.34,2005

経済研究所経済制度研究センター（編）(4) 227-264 (5) 03/12

\section{〈ラオ ス〉}

(1)岩田 明久, 大西 信弘，木口 由香(2)南部ラオスの平野部における魚類の生息場 所利用と住民の漁労活動(3)ジア・アフリカ地域研究 3 (京都大学) (4) 51-86 (5) 03/11

(1)園江 満(2)ラオスの統計制度(3)開発学研究 14(3) (4) 60-66 (5) 04/03

(1)千頭 聡, 上杉 圭子(2)ラオス北部焼畑地域における土地利用政策の効果と課題(3) 環境情報科学〈別冊〉環境情報科学論文集 17 (4) 375-380 (5) 03/11

(1)中田 友子(2)南ラオスの民族混住村における水牛供犠祭り(3)東南アジア研究 42(1) (4) 74-103 (5) 04/06

(1)百村 帝彦(2)地域住民による土地利用と非木材森林産物との関連：ラオス・サワン ナケート県の事例研究(3)熱帯農業 48 (EXTRA 1) (4) 97-98 5) 04/03

(1)山田 紀彦(2)ラオス内戦下の国民統合過程：パテート・ラーオの民族政策と「国民」 概念の変遷(3)一般：武内（編）(4) 147-185 (5) 03/12

\section{〈そ の 他〉}

(1)金 栄(2)雲南省の「玉砕」地の「慰安所」(3)季刊戦争責任研究 42 (4) 75-83 (5) 03/12

(1)武内 剛(2)雲南イ族におけるエスニシティの動態(3)人文紀要 39(3)（名城大学) (4) 11-20 (5) 04/03

(1)長谷 千代子(2)他者とともに空間をひらく：雲南省芒市の関公廟をめぐる徳宏タイ 族の実践(3)社会人類学年報 30 (4) 63-87 (5) 04/09

(1)林 謙一郎(2)大理国史研究の視角(3)文学部研究論集・史学 50 (名古屋大学) (4) 120 (5) $04 / 03$

(1)元木 靖, ビラルディン・ニザム(2)ハニ族の棚田：中国・雲南省元陽県の事例研究 (3)埼玉大学紀要 39(2) (4) 181-205 (5) 04/03

(1)百瀬 邦泰(2)雲南の棚田地帯を涵養する雲霧帯の土地利用の変遷と竜山の消長(3ア ジア・アフリカ地域研究 3 (京都大学) (4) 87-102 (5) 03/11 